\title{
Physicochemical Properties of Handere Clays and Their Use as a Building Material
}

\author{
Yasin Erdoğan \\ Department of Petroleum \& Natural Gas Engineering, Faculty of Engineering, Mustafa Kemal University, \\ Iskenderun, 31200 Hatay, Turkey
}

Correspondence should be addressed to Yasin Erdoğan; erdogan@mku.edu.tr

Received 1 April 2015; Revised 6 May 2015; Accepted 7 May 2015

Academic Editor: Fa-Nian Shi

Copyright (C) 2015 Yasin Erdoğan. This is an open access article distributed under the Creative Commons Attribution License, which permits unrestricted use, distribution, and reproduction in any medium, provided the original work is properly cited.

Handere clay deposits were discovered at Adana in Turkey. These clay units primarily consist of uncoloured claystone, pebbly sandstone, sandstone, siltstone, and mudstone marl and include gypsum lenses and clay levels of various thicknesses in places. The physicochemical properties of these clays have been investigated by different techniques including Scanning Electron and Elemental Analysis (SEM and EDS), mineralogical analyses, chemical and physical analyses, X-ray diffraction (XRD), thermogravimetric differential thermal analysis (TG-DTA), and Atterberg (Consistency) Limits Test. The mineralogical composition deduced from $\mathrm{XRD}$ is wide (smectite + palygorskite + illite \pm feldspar \pm chlorite \pm quartz \pm calcite \pm serpentine) due to the high smectite contents $(\approx 85 \%)$. SEM studies reveal that smectite minerals are composed of irregular platy leaves and show honeycomb pattern in the form of wavy leaves in places. The leaves presenting an array with surface edge contact are usually concentrated in the dissolution voids and fractures of volcanic glass. Organic matter content and loss on ignition analysis of raw materials are good for all the studied samples. In summary, Handere clays can be used as building materials in bricks, roof tiles, and cement and as a binder.

\section{Introduction}

Human beings found various applications of layered clay minerals since prehistoric civilization due to their widespread distribution and a great diversity of reactions in nature. Depending on the layer structure and specific properties, such as high specific surface area, ion exchange capacity, or hydration property, clay minerals were widely used in ceramics and building materials, paper industries, oil drilling, foundry moulds, and pharmaceuticals and were also used as adsorbents, catalysts or catalyst supports, ion exchangers, and decolourizing agents [1-5].

Clay minerals are a class of phyllosilicates which usually form as a result of chemical weathering of other silicate minerals at the surface of the earth. This mineral mostly contains limestone, silica, mica, and iron oxide and has a yellowish, reddish, or brown colour. Clay is a valid concept for decomposition products generated by hydrothermal activity and for particles deposited by sedimentation, and chemical classifications were made according to the minerals comprising such small particles [6-10].
Clay minerals are included in kaolinite, halloysite, illite, chlorite, smectite, and attapulgite groups according to their chemical composition and formation. Clay minerals which used to be called montmorillonite group are referred to as smectite. Smectite minerals are composed of two silica tetrahedral layers and a single $\mathrm{Al}$ octahedral layer. Important smectite group minerals include montmorillonite, beidellite, nontronite, hectorite, saponite, and sauconite. The minerals in this group have a density of $2-3 \mathrm{gr} / \mathrm{cm}^{3}$ and hardness between 1 and 2 [11-13].

Depending on the amount of water mixed into them, clays exhibit a variety of properties, including plasticity, fluidity, and colloidal and thixotropic properties. These various properties affect industrial and engineering use of clay minerals [14-18]. Chemical composition of various clay minerals was presented in Table 1.

In this study, Handere clays were investigated in order to characterise the raw material available at Adana in Turkey. The study covered over approximately $20 \mathrm{~km}$ including Handere formation (Figure 1). 
TABLE 1: Chemical composition of various clay minerals [17].

\begin{tabular}{lcccccccccc}
\hline Clay & $\mathrm{SiO}_{2}$ & $\mathrm{Al}_{2} \mathrm{O}_{3}$ & $\mathrm{Fe}_{2} \mathrm{O}_{3}$ & $\mathrm{MgO}$ & $\mathrm{CaO}$ & $\mathrm{K}_{2} \mathrm{O}$ & $\mathrm{Na}_{2} \mathrm{O}$ & $\mathrm{TiO}_{2}$ & $\mathrm{H}_{2} \mathrm{O}$ & $\mathrm{Total}$ \\
\hline Kaolinite & 46.90 & 37.40 & 0.66 & 0.27 & 0.29 & 0.84 & 0.44 & 0.18 & 12.95 & 99.92 \\
Nacrite & 44.75 & 39.48 & 0.53 & 0.19 & 0.13 & 0.34 & 0.22 & - & 14.40 & 100 \\
Stalagmites & 46.86 & 37.12 & 1.43 & 0.09 & 0.22 & 0.60 & 0.07 & 0.51 & 12.99 & 99.89 \\
Halloysite & 44.75 & 36.94 & 0.31 & - & 0.11 & 0.60 & - & - & 17.42 & 100.01 \\
Anauxite & 54.32 & 29.96 & 2.00 & 0.14 & 0.32 & - & 0.37 & - & 12.64 & 99.75 \\
Nontronite & 40.54 & 5.19 & 31.63 & 0.06 & 1.92 & 0.24 & 0.14 & - & 20.75 & 100.47 \\
Chlorite & 31.44 & 17.62 & - & 37.64 & - & - & - & - & 13.19 & 99.89 \\
Prochlorite & 23.69 & 21.26 & 26.52 & 17.60 & 3.22 & - & - & - & 7.63 & 99.92 \\
Sepiolite & 52.50 & 0.60 & 2.99 & 21.31 & 0.47 & - & - & - & 21.27 & 99.14 \\
Attapulgite & 57.85 & 7.89 & 2.82 & 13.44 & 0.30 & 0.08 & 0.53 & - & 16.95 & 99.86 \\
\hline
\end{tabular}

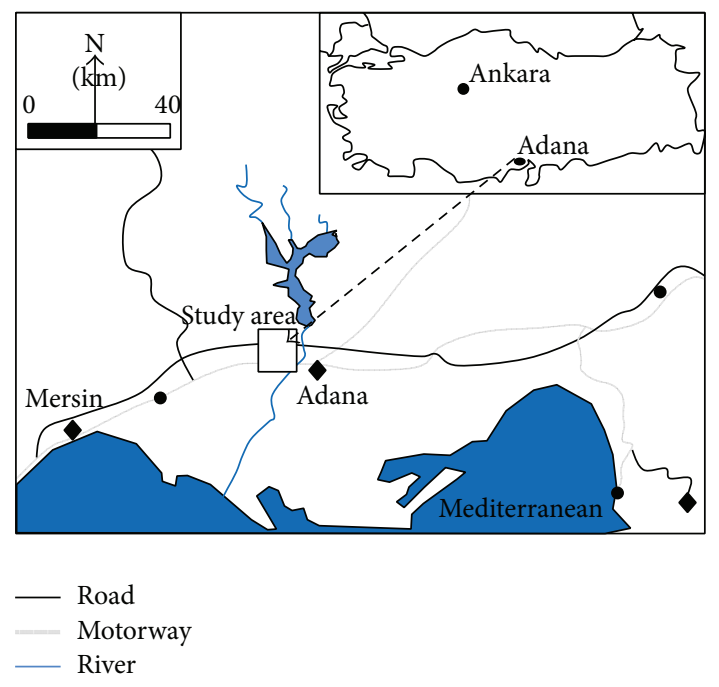

Figure 1: Location of studied area at Handere in Turkey.

Their best uses require an exact knowledge of their physicochemical properties. This paper describes studies of crude clay samples with a set of techniques comprising mineralogical analyses, Scanning Electron Microscope (SEM), Elemental Analysis (EDS), chemical and physical analyses, X-ray diffraction (XRD), thermogravimetric-differential thermal analysis (TG-DTA), and Atterberg (Consistency) Limits Test. In addition, organic matter content and loss on ignition analysis of raw materials test were performed for determination of applicability of the material as a building material. The work had three distinct aims:

(1) To identify Handere clay present in different samples and its purity and associated minerals.

(2) To characterise the physicochemical properties of the clay to enable assessment of its suitability for different uses.

(3) To determine applicability of the material as a building material.

\section{Geological Description of Handere Clays}

Clay deposits investigated in the present study are from a cluster at Adana in Turkey. Handere geological formation was named by Schmidt in 1961 [19]. The unit primarily consists of uncoloured claystone, pebbly sandstone, sandstone, siltstone, and mudstone marl and includes gypsum lenses and clay levels of various thicknesses in places. Trough crossstratification in pebbles and parallel lamination in those with tiny particles are observed. The thickness of the formation is in the range of 120 to $700 \mathrm{~m}$ [20]. The bottom unit has a transitional contact on Kuzgun formation, and the top unit covered by young alluvial deposits in places has a widespread terrace set formation of Adana basin. According to the fossil groups discovered in the formation, the formation is assigned a Messinian-Pliocene age. The study samples representative of the area were collected, classified by sieving them $(0.2$ to $2 \mathrm{~mm}$ ) at the laboratory, and made ready for tests [21-24].

\section{Chemical Composition}

Samples representative of the area were collected from Handere formation and chemical analyses were performed in order to determine their chemical composition. Chemical analysis of the samples was performed using XRF device (Siemens SRS 300 X-Ray Fluorescence Spectrometer) after they were dried at $105^{\circ} \mathrm{C}$. The results obtained from the analyses are given in Table 2 . When the results were interpreted, it was identified that the clay content (\%) is largely composed of $\mathrm{SiO}_{2}$ (mean: $61.71 \pm 0.21$ ) and $\mathrm{Al}_{2} \mathrm{O}_{3}$ (mean: $16.42 \% \pm$ 0.58 ) and the clay group contains smectite mineral, and these results were consistent with previous studies in the literature.

\section{Petrographic Studies}

Thin sections with a thickness of $0.02 \mathrm{~mm}$ were prepared from clays. These sections were examined by polarizing microscope. As a result of their microscopic examinations, it was determined that the clay is smectite, a type of clay mineral rich in silica $(\mathrm{Si})$ and aluminum $(\mathrm{Al})$. The smectite mineral was found to contain amorphous silica, calcite, chlorite, quartz, and illite minerals. 
TABLE 2: The results of chemical analysis of Handere clay (\%).

\begin{tabular}{lcc}
\hline Chemical composition & Mean & Standard deviation \\
\hline $\mathrm{SiO}_{2}$ & 61.71 & 0.21 \\
$\mathrm{Al}_{2} \mathrm{O}_{3}$ & 16.42 & 0.58 \\
$\mathrm{Na}_{2} \mathrm{O}$ & 2.26 & 0.19 \\
$\mathrm{~K}_{2} \mathrm{O}$ & 4.58 & 0.24 \\
$\mathrm{Fe}_{2} \mathrm{O}_{3}$ & 7 & 1.76 \\
$\mathrm{CaO}+\mathrm{MgO}$ & 3.92 & 0.33 \\
Others & 4.12 & 1.83 \\
\hline
\end{tabular}

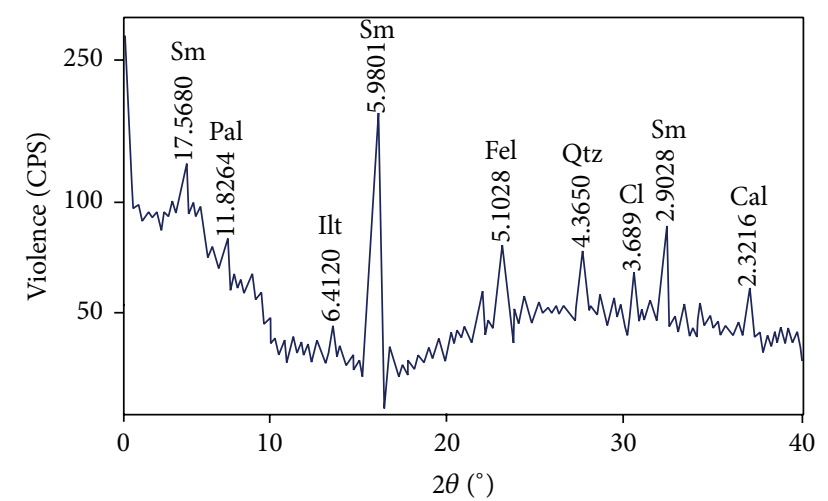

$\begin{array}{ll}\text { Sm: smectite } & \text { Qtz: quartz } \\ \text { Pal: palygorskite } & \text { Cal: calcite } \\ \text { Ilt: illite } & \text { Cl: chlorite } \\ \text { Fel: feldspar } & \end{array}$

Figure 2: X-ray diffraction patterns for a Handere clay sample (glycol solvated).

\section{Mineralogical Composition (XRD)}

Mineralogical analysis was conducted on the samples in powder form by $\mathrm{Cu} \mathrm{X}$-ray tube Rigaku Geigerflex XRD apparatus. As a result of phase (mineralogical) analysis, it was revealed that the clay samples are largely comprised of smectite 14 (85\%), followed by palygorskite, illite, feldspar, chlorite, quartz, calcite, and trace amounts of serpentine in decreasing order of abundance (Figure 2).

\section{Scanning Electron Microscope (SEM)}

Clay samples were enlarged in the range of $105-170 \mu \mathrm{m}$ and were examined by image analysis system and their photographs were taken (Figure 3). It is clear that clay samples are smectite clay minerals. Smectite minerals are composed of irregular platy flakes and show honeycomb pattern in the form of wavy leaves in places. The flakes presenting an array with surface edge contact are usually concentrated in the dissolution voids and fractures of volcanic glass. In addition, smectite flakes show growth towards the pores.

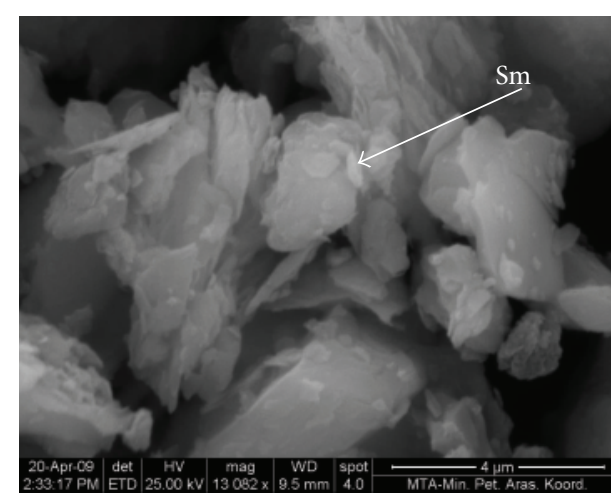

FIGURE 3: SEM image of Handere clay (smectite).

\section{Elemental Analysis (EDS)}

SEM analysis and EDS (energy dispersive spectrometer) and point (elemental) analyses of the samples were performed and distribution percentages of the elements were determined. EDS point analysis was conducted using EDAX Genesis XM $4 \mathrm{i}$ model detector. The clay samples were identified to have oxygen $(46.95 \%)$, silica (27.3\%), aluminum (7.11\%), and iron (2.53\%) (Figure 4).

\section{TG-DTA Analysis}

According to TG curve of the clay (smectite) sample, the sample lost its moisture at about $50-100^{\circ} \mathrm{C}$. In DTA analysis, the mass loss was not significant until $480^{\circ} \mathrm{C}$, and the endothermic peak at $713.4^{\circ} \mathrm{C}$ supported that thermal degradation took place between 480 and $800^{\circ} \mathrm{C}$. In TG curve, it was determined that there was no mass loss after $790^{\circ} \mathrm{C}$ and the total mass loss was about 5.5\%. Sintering started at around $440^{\circ} \mathrm{C}$ and was complete at $700^{\circ} \mathrm{C}$. The reaction decomposition started at $810^{\circ} \mathrm{C}$, made an endothermic peak at about $834.6^{\circ} \mathrm{C}$, and was complete at $855^{\circ} \mathrm{C}$ (Figure 5). In a literature review, it has been found to show similar characteristic of clay in the Mediterranean zone [12, 21, 2527].

\section{Physical Properties}

In order to determine the physical properties (loose unit weight, specific gravity, porosity, water absorption, and compactness ratio) of Handere clays, the samples were ground and sieved through sieves with $1 \mathrm{~mm}$ of sieve opening and their impurities were removed. Their loose unit weight analyses were conducted in accordance with TS 3529 and TS 1114 standards $[28,29]$. The results obtained from the analyses are given in Table 3.

\section{Atterberg (Consistency) Limits Test of Handere Clays}

Water content values defined by Atterberg, a Swedish chemist, are used to determine consistency limits of soils 


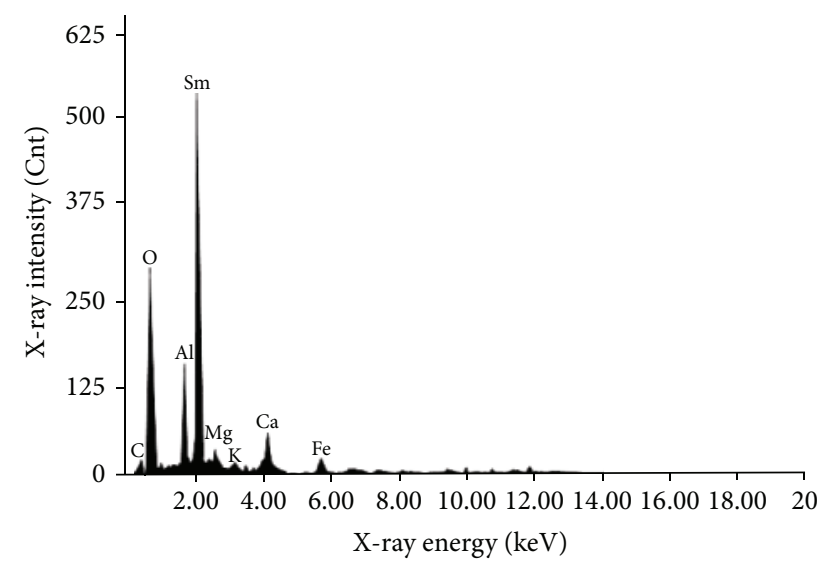

FIGURE 4: EDS analysis of Handere clay.

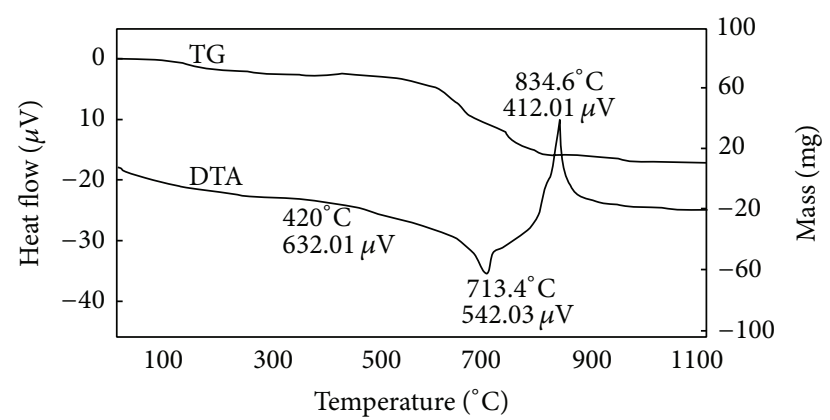

FIgURE 5: Clay example $20^{\circ} \mathrm{C} / \mathrm{min}$. heating rate conversion TG-DTA curves.

TABLE 3: The results of the physical analysis of Handere clay.

\begin{tabular}{lcc}
\hline Tests & Mean & Standard deviation \\
\hline Unit weight $\left(\mathrm{gr} / \mathrm{cm}^{3}\right)$ & 1.32 & 0.06 \\
Specific gravity $\left(\mathrm{gr} / \mathrm{cm}^{3}\right)$ & 2.73 & 0.02 \\
Porosity (\%) & 12.80 & 1.60 \\
Water absorption (\%) & 52.64 & 2.65 \\
Compactness ratio (\%) & 0.46 & 0.03 \\
\hline
\end{tabular}

[30]. In the present study, Casagrande method was used to determine the consistency limits of Handere clays [31].

As a result of the test, liquid limit and plastic limit were $52 \%$ and $23 \%$, respectively. According to these results, calculated plasticity index, PI, was $29 \%$, and the soil class was identified as highly plastic clay.

\section{Tests for Determination of Applicability of the Material as a Building Material}

Limit values of a material to be used in the building and construction sector should be determined by examining the general structural characteristics of that material. For this purpose, whether the clay mineral is suitable to be used as a building material was investigated by organic matter content and loss on ignition analyses.

\section{Organic Matter Content}

Presence of organic matters in a raw material is inconvenient and undesirable. Organic compounds particularly reduce the strength of a building material, cause corrosion and softening in the material over time, and, most importantly, make natural and chemical materials, which are used as binders, lose their binding properties. As a result of the test conducted according to the test criteria indicated in TS EN 1744-1 and TS 4790 [32-34], Handere clays were found to contain no organic matter. The results of chemical analysis conducted on the clay are consistent with the results obtained from this test.

\section{Loss on Ignition Analysis of Raw Materials}

At high temperatures, as in the case of a fire, the composition of aggregate and natural binder materials, used in the manufacture of building materials in the construction industry, deteriorates, and such materials undergo mass loss. Therefore, whether a raw material intended for use in the construction industry undergoes any mass loss as a result of the effect of temperature should be determined.

According to the results obtained from loss on ignition analyses, loss on ignition of Handere clays was determined as $4.85 \%$. As stipulated in the standard, TS 1114 , the maximum loss on ignition of a raw material can be $5 \%$ by weight. TS 1114 stipulates that if the loss by weight of a raw material at maximum temperature is $\leq 5 \%$, it can be used as a raw material in bricks, cement, and roof tiles.

According to the analysis results, it was determined that the clays of the region can be used as building materials in bricks, roof tiles, and cement and as a binder; however, they cannot be used in the production of ceramics, porcelain, glass, and tiles.

\section{Conclusion}

In this study, material properties of the clays from Handere formation were investigated in order to determine their applicability as a building material. As a result of petrographic and chemical analyses, it was determined that the clays were smectite, a clay mineral rich in $\mathrm{Si}$ and $\mathrm{Al}$. The smectite mineral was found to contain amorphous silica, calcite, chlorite, quartz, and illite. According to the results of qualitative mineralogical (XRD) analyses, the samples were found to be largely comprised of smectite 14 (85\%), followed by palygorskite, illite, feldspar, chlorite, quartz, calcite, and trace amounts of serpentine in decreasing order of abundance.

In SEM examinations, it was seen that the clay samples are smectite clay minerals. Smectite minerals are composed of irregular platy leaves and show honeycomb pattern in the form of wavy leaves in places. In elemental (EDS) analyses, the clay samples were identified to have oxygen (46.95\%), silica (27.3\%), aluminum (7.11\%), and iron (2.53\%).

In TG-DTA analysis, the mass loss was not significant until $480^{\circ} \mathrm{C}$, and the endothermic peak at $713.4^{\circ} \mathrm{C}$ supported the fact that thermal degradation took place between 480 and $800^{\circ} \mathrm{C}$. In TG curve, it was determined that there was no mass loss after $790^{\circ} \mathrm{C}$ and the total mass loss was about $5.5 \%$. 
Consistency limits of Handere clays were established, and, at the end of the test, a liquid limit of $52 \%$ and a plastic limit of $23 \%$ were found. According to these results, calculated plasticity index was $29 \%$ and the soil class was identified as highly plastic clay.

As a result of the studies performed according to test criteria specified in EN 1744-1, no organic matter was found in Handere clays. According to the results of loss on ignition analyses conducted according to TS 1114 standard, loss on ignition of Handere clays was $4.85 \%$. When the results were examined, loss on ignition of the clays was less than $5 \%$, so it was determined that the clays can be used as aggregate raw materials in the production of bricks and lightweight building materials.

In conclusion, when the studies and the analysis results were evaluated together, it was established that the clays from the region can be used as building materials, including bricks, roof tiles, and fillers; however, they cannot be used in the production of ceramics, porcelain, glass, and tiles.

\section{Conflict of Interests}

The author declares that there is no conflict of interests regarding the publication of this paper.

\section{References}

[1] A. Vaccari, "Preparation and catalytic properties of cationic and anionic clays," Catalysis Today, vol. 41, no. 1-3, pp. 53-71, 1998.

[2] M. I. Carretero and G. Lagaly, "Clays and health: an introduction," Applied Clay Science, vol. 36, no. 1-3, pp. 1-3, 2007.

[3] C. Nkoumbou, F. Villieras, D. Njopwouo et al., "Physicochemical properties of talc ore from three deposits of Lamal Pougue area (Yaounde Pan-African Belt, Cameroon), in relation to industrial uses," Applied Clay Science, vol. 41, no. 3-4, pp. 113132, 2008.

[4] D. Zhang, C.-H. Zhou, C.-X. Lin, D.-S. Tong, and W.-H. Yu, "Synthesis of clay minerals," Applied Clay Science, vol. 50, no. 1, pp. 1-11, 2010.

[5] R. Srinivasan, "Advances in application of natural clay and its composites in removal of biological, organic, and inorganic contaminants from drinking water," Advances in Materials Science and Engineering, vol. 2011, Article ID 872531, 17 pages, 2011.

[6] R. B. Grim, Clay Mineralogy, McGraw-Hill, New York, NY, USA, 2nd edition, 1953.

[7] G. S. Odin, "Observations on the structure of glcuconite vermicular pellets," Sedimentalogy, vol. 19, pp. 204-285, 1972.

[8] H. Tanişan and Z. Mete, "Ceramic technology and application," in Proceedings of the Ceramic Congress, pp. 23-34, Istanbul, Turkey, 1985.

[9] R. L. Vitra, U.S. Geological Survey, Mineral Commodity Summaries, Clays, San Antonio, Tex, USA, 2009.

[10] A. Nzeugang Nzeukou, N. Fagel, A. Njoya, V. Beyala Kamgang, R. Eko Medjo, and U. Chinje Melo, "Mineralogy and physicochemical properties of alluvial clays from Sanaga valley (Center, Cameroon): suitability for ceramic application," Applied Clay Science, vol. 83-84, pp. 238-243, 2013.

[11] Y. Erdoğan, "Engineering properties of Turkish travertines," Scientific Research and Essays, vol. 6, no. 21, pp. 4551-4566, 2011.
[12] A. G. Çelik and A. M. Kiliç, "Characteristic properties of Ankara (imrahor) clays and its use as a construction," in Proceedings of the 8th International Industrial Minerals Symposium, pp. 243252, Istanbul, Turkey, 2012.

[13] A. G. Çelik, A. M. Kiliç, and G. Ö. Çakal, "Expanded perlite aggregate characterization for use as a lightweight construction raw material," Physicochemical Problems of Mineral Processing, vol. 49, no. 2, pp. 689-700, 2013.

[14] G. Rajasekaran, K. Murali, and R. Srinivasaraghavan, "Microfabric, chemical and mineralogical study of Indian marine clays," Ocean Engineering, vol. 26, no. 5, pp. 463-483, 1998.

[15] D. Ogle, "Making lightweight refractory ceramic from perlite and clay," Aprovecho Research Center, pp. 2-7, 2003.

[16] C. E. Weaver, "The clay petrology of sediments," in Clays and Clay Minerals: Proceedings of the 6th Conference, vol. 566, pp. 154-187, Pergamon Press, New York, NY, USA, 1959.

[17] R. L. Vitra, "U.S. geological survey, mineral commodity summaries," Clays, 2008.

[18] Y. Erdogan, Investigation of engineering properties of building materials made with acidic and alkaline pumice [Ph.D. thesis], Cukurova University, Institute of Science, Adana, Turkey, 2007.

[19] G. C. Schmidt, "Stratigraphic nomenclature for the Adana region petroleum district VII," Petroleum Administration Bulletin, vol. 6, pp. 47s-63s, 1961.

[20] C. Yetis and C. Demirkol, "Detailed study of the western part of the Adana basin," M.T.A. Compilation Report 8037, 1986.

[21] A. Palali, The effect of changing of water content and compaction energy to strength in Handere clay [M.S. thesis], Cukurova University, Institute of Science, Adana, Turkey, 2006.

[22] T. Rusen, Uniaxial strength of the effect of sample size on clayey soils [M.S. thesis], Geological Engineering Department, Science institute, Cukurova University, Adana, Turkey, 2011.

[23] S. Özkan, E. Yaşar, Y. Erdogan et al., "Salbas (Adana) sandstones of usability evaluation of industrial area," in Proceedings of the 20th International Mining Congress and Exhibition of Turkey, pp. 259-268, Ankara, Turkey, 2007.

[24] E. Yaşar and Y. Erdoğan, "Strength and thermal conductivity in lightweight building materials," Bulletin of Engineering Geology and the Environment, vol. 67, no. 4, pp. 513-519, 2008.

[25] M. A. Rahman and M. Muneer, "Photocatalysed degradation of two selected pesticide derivatives, dichlorvos and phosphamidon, in aqueous suspensions of titanium dioxide," Desalination, vol. 181, no. 1-3, pp. 161-172, 2005.

[26] M. C. Wu, S. L. Kuo, J. C. Lin, C. M. Ma, G. B. Hong, and C. T. Chang, "Studies on certain physical properties of modified smectite nanocatalysts," Applied Surface Science, vol. 257, no. 13, pp. 5641-5646, 2011.

[27] A. Sandler, "Clay distribution over the landscape of Israel: from the hyper-arid to the Mediterranean climate regimes," Catena, vol. 110, pp. 119-132, 2013.

[28] TS 3529, Specific Weight and Absorption Determination of Concrete Aggregates, 1980.

[29] TS 1114 EN 13055-1, Lightweight Aggregates-Part 1: for Use in Concrete, Mortar and The Juice, 2004.

[30] T. W. Lambe, Soil Testing for Engineers, John Wiley \& Sons, New York, NY, USA, 1951.

[31] A. Casagrande, "Classification and identification of soils," Transactions of the American Society of Civil Engineers, vol. 113, pp. 901-930, 1948.

[32] TS EN 1744-1, “Tests for Chemical Properties of Aggregates, Part 1: Chemical Analysis," 2000. 
[33] TS 4790, Experimental Methods of Soil Bricks and Tiles, 1986.

[34] W. Hamza, C. Chtara, and M. Benzina, "Retention of organic matter contained in industrial phosphoric acid solution by raw Tunisian clays: kinetic equilibrium study," Journal of Chemistry, vol. 2013, Article ID 218786, 9 pages, 2013. 

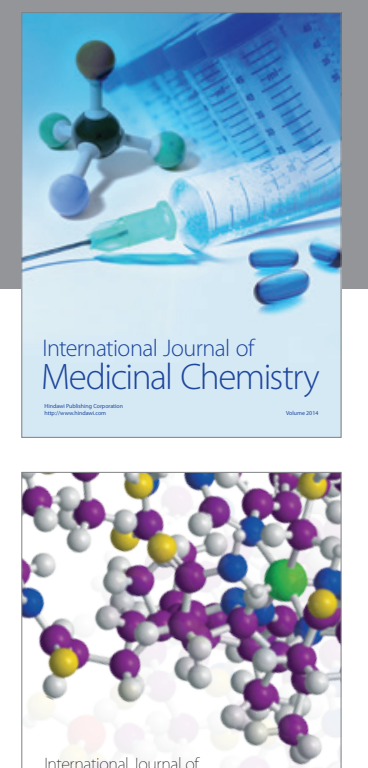

\section{Carbohydrate} Chemistry

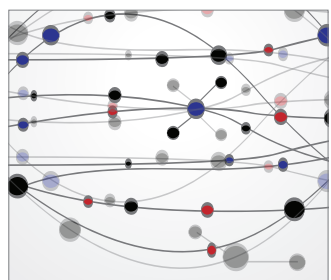

The Scientific World Journal
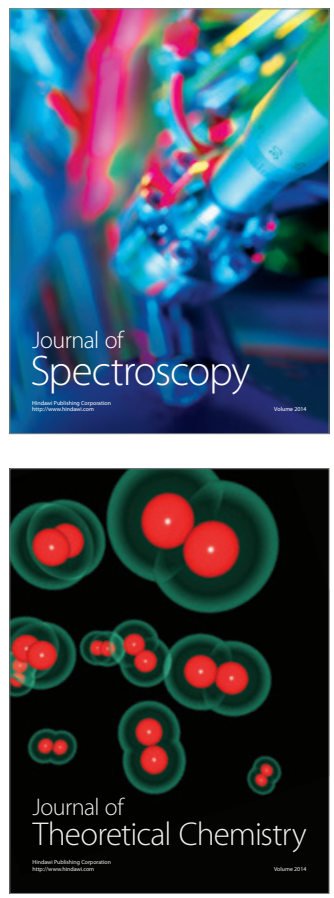
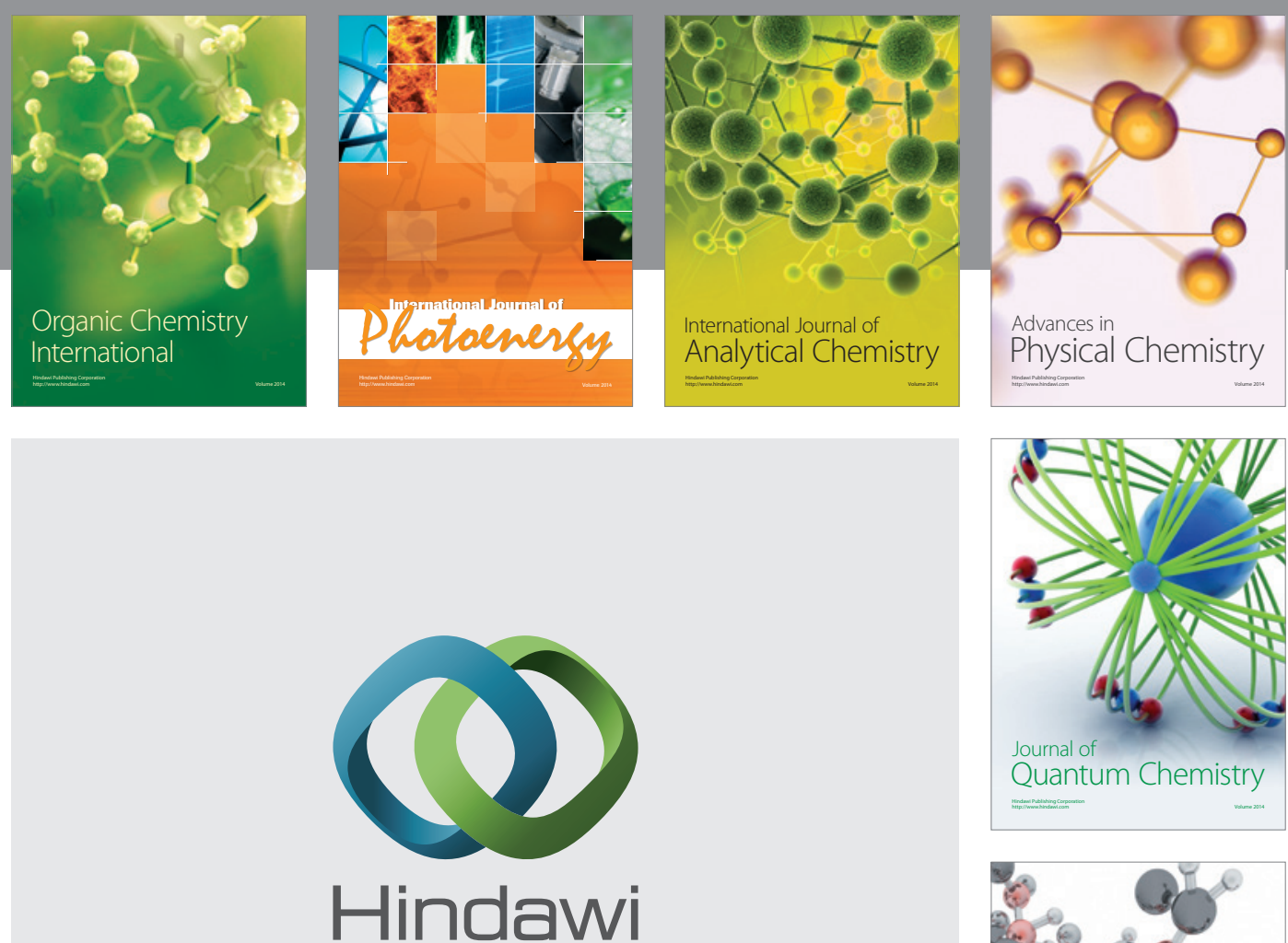

Submit your manuscripts at

http://www.hindawi.com

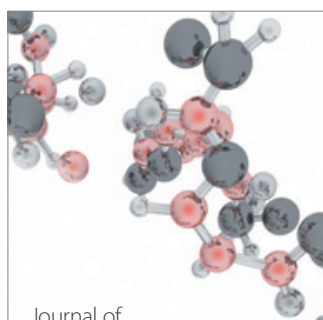

Analytical Methods

in Chemistry

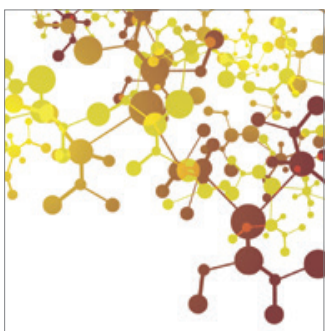

Journal of

Applied Chemistry

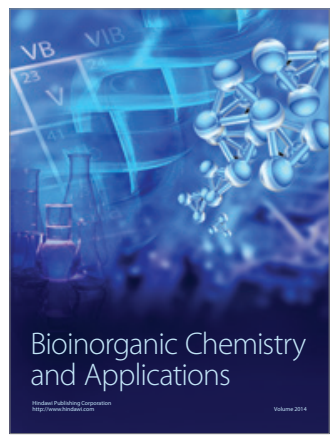

Inorganic Chemistry
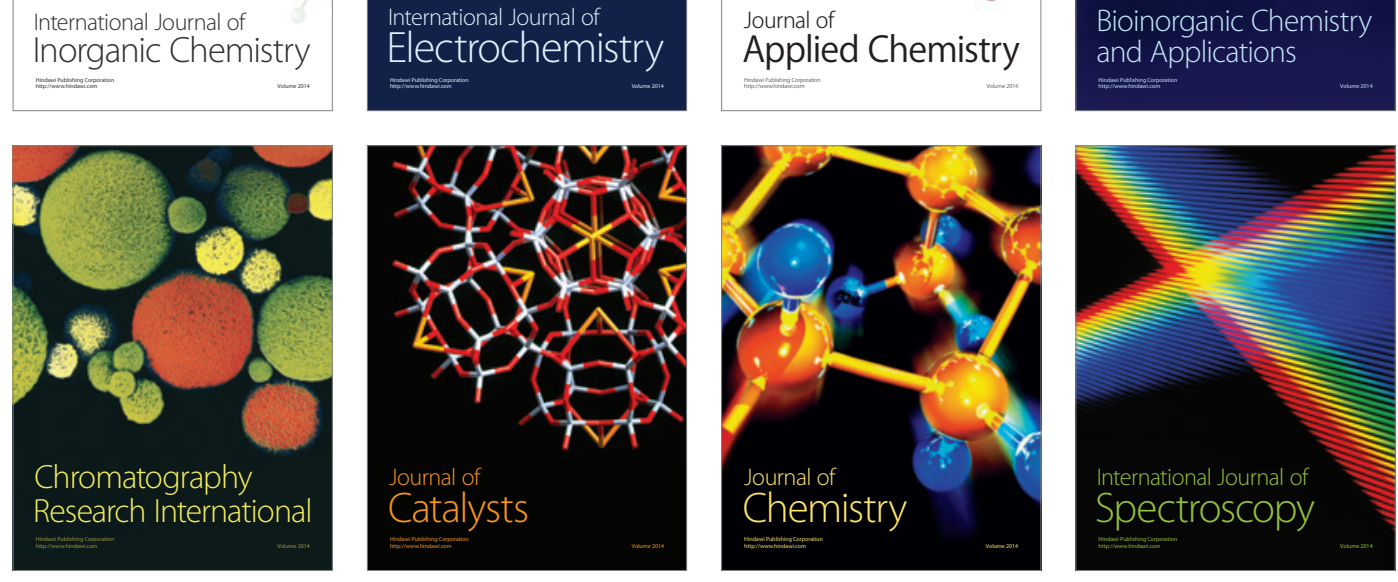